\title{
CHAPTERTWO
}

\section{Female imperialism at the periphery: organizing principles, 1900-19}

From the beginning of the twentieth century, it was a common sight to see members of the IODE frequenting Canada's major ports. Proudly pinned to their smartest clothes were their badges with Union Jack, crown and stars radiating outwards to the corners of the Empire. In a close working relationship with government, taking advantage of elite contacts and putting forward its maternal role, the IODE negotiated a position to welcome immigrants from many countries at ports of arrival. A 1904 article by Mabel Clint commented that at the Port of Quebec ' $[\mathrm{t}]$ he wearers of the badge have been the only outsiders allowed in the Immigration Buildings after the arrival of an ocean liner, and have met with every courtesy from the officials'. ${ }^{1}$ The 'wearers of the badge' thus began their work commanding a respect that they would sustain and extend in future years.

The IODE was greatly excited by, as well as concerned about, the arrival of immigrants. As part of its mission to produce a Canada that mimicked Britain, the IODE sought British immigrants to populate Canadian space. A framework of powerful racial preferences was constructed as the norm to which all others must assimilate. Examining the preference for British immigrants, this chapter shows how, as was the case with other ethnic labels, 'Britishness' was very much an invented tradition.

During the early years of the twentieth century women's place was often ideally located as a wife, mother or daughter in private domestic space. The IODE was involved in utilizing such maternal identity in the production of its own brand of female imperialism. As Dominic Alessio suggests in his examination of female personifications in the 'white' British 'colonies' from 1886 to 1940, women were constructed as 'agents of civilization', their role moving beyond the symbolic to that of active racial and moral agents. ${ }^{2}$ As Anna Davin articulated in 1978, such maternal civilizing work was deeply infused with race ideology and 
population dynamics. ${ }^{3}$ More recently, Mariana Valverde has documented the commonplace discussion of 'race degeneration', eugenics and salvation through social purity among a broad spectrum of Canadian women's organizations. ${ }^{4}$ In this vein, the IODE was very outspoken, and made extremely strong connections between race and populating Canada, that it then sought to enact. The First World War provided the opportunity for the IODE, backed by such ideology, to exert its energies in defence of the Empire.

\section{Constructing Anglo-Celts and racial hierarchies}

The IODE forthrighly articulated belief in a 'British' race, and it is important to survey the implications of Britishness in the Canadian context. Kay Anderson's work on Canadian racial discourse in Vancouver's Chinatown makes visible the components of such racism, reading Chinatown as a representation of Anglo-Celtic Canadians' hegemonic constructions of race. ${ }^{5}$ Studies attempting to show 'the British' or 'the English' as an ethnic group in Canada are very recent and are testimony to the extent of the hang-over of hegemonic constructions of Britishness. ${ }^{6}$ The lack of attention is also to do with the tension in treating the English the same as other ethnic groups. As Greenhill cautions, 'there is a danger that a valorized English ethnicity will be linked with power in such a way as to make it even more hegemonic, a culture to which all others must aspire. But invisibility is also problematic; subversive parodies and travesties of power are impossible when its workings are unrecognised. ${ }^{7}$ Rather than become entangled in whether Englishness or Britishness was or was not ethnic, it is more helpful to look to the localized invention of Britishness. Catherine Hall's anti-essentialist conceptualization of identity is useful. She considers the make-up of mid-nineteenth-century Englishness to 'unpick the stories which gave meaning to the national and imperial project, and to understand the ways in which English identity was constructed through the active silencing of the disruptive relations of ethnicity, gender and of class'. Rather than reconstituting she attempts to destabilize Englishness, uncovering contingency in its historic specificity, and looking at the dependences, inequalities and oppressions which were hidden in its celebration of national identity. ${ }^{8}$

In considering 'contingency', 'historic specificity' and the silencing of difference, Hall's approach has much in common with that of Robert Young, who argues that 'Englishness' was 'fissured with difference and a desire for otherness'. ${ }^{9}$ This was clearly the case in Canada, where the construction of Britishness was unique. The identity of 'the English' or 'the Anglo-Canadian' has often uncritically blended the English, Irish, 
Scottish and Welsh into a single group. Greenhill suggests that this confusion was deliberate and served to disempower other groups: 'English ethnicity's most salient characteristics are submerged by a variety of forces that make its hegemonic status obscure. ${ }^{10}$ As Howard Palmer suggests, 'Anglo-Celts', Canadians of English, Scots, Welsh or Irish descent, did not always think of themselves as an undifferentiated group: 'They could and did have differences of opinion among themselves when it came to their own ethnic identity. But when it came to the other ethnic groups, the Anglo-Celts closed ranks. ${ }^{11}$ It is this closing of ranks, what it was composed of, and how it retained and fostered its dominance, that interests me. Tangled up with the policies and thought of the time, here, the IODE's history provides much insight.

Theories of race had a great influence on the IODE; members attended lectures and read books and articles to keep well-versed on contemporary developments. One book that contained ideology which influenced the IODE was J. S. Woodsworth's The Stranger at Our Gates. In 1909, the Canadian reformer and founder of the Co-operative Commonwealth Federation, in a book sponsored by the Methodist Church, captured the prevailing Canadian 'racial hierarchy'. ${ }^{12}$ Immigrants were ordered according to proximity to a British core, and the 'unusual' races were to be welcomed in the degree to which they approached the ideal of 'Anglo-Saxons', the British and the Americans first, followed by the Northwestern, then the Central and Eastern Europeans, then the Jews, the Asians and the blacks. This hierarchy of races was reflected in Canadian immigration law, where British immigrants were legislated as the 'first choice'. An Act in 1906 consolidated and revised all immigration legislation since 1869. ${ }^{13}$ A 1910 Act excluded persons deemed undesirable because of 'climatic, industrial, social, educational, labour or other conditions or requirements of Canada or deemed undesirable because of their customs, habits, modes of life and methods of holding property and their probable inability to become readily assimilated ${ }^{14}$ Such subjective categorizing left the way open to favour preferences for British origins.

It was during the early years of the twentieth century that the IODE formed and solidified its own racial ideology. Its beliefs were steeped in powerful ideas of the time, such as the superiority of an Anglo-Celtic race that was interpreted as being biological, and which was demonstrable from imperial conquests such as the South Africa War. It drew upon a diversity of racial theories, and Darwin was invoked to give scientific credibility to the theory of Anglo-Celtic superiority, ${ }^{15}$ while it was widely believed that 'the breeding of humans followed the same mendelian laws and was as predictive in nature as that of other sexually 
reproducing organisms'. ${ }^{16}$ In 1883 Galton coined the term 'eugenics' to describe 'the study of the agencies under social control that may improve or impair the racial qualities of future generations, either physically or mentally'. ${ }^{17}$ As Angus MacLaren has suggested, eugenic arguments also claimed scientific justifications for deep-seated gendered, racial and class assumptions. ${ }^{18}$ The belief that race could be scientifically controlled and manipulated led to calls for 'race regeneration' and 'purity'. There was new faith in the efficacy of regulation, management, administration and science in remaking society. ${ }^{19}$ As Carol Bacchi and Mariana Valverde have argued, women, as mothers, had an important part to contribute to the cleaning-up of the 'lesser races' ${ }^{20}$ Furthermore, it was believed that racial improvement could be brought about by improved environmental immersion. $^{21}$

Geographers such as Ellsworth Huntington and Griffith Taylor promoted the idea that the character of a race was influenced by physical environment, natural selection and historical development. ${ }^{22}$ As Livingstone notes, 'the idioms of political and moralistic evaluation were simply part and parcel of the grammar of climatology'. ${ }^{23}$ Environmental suitability was used to justify the racial hierarchies such that the Northern European races were suited to Canada. As Marilyn Barber has written:

$[\mathrm{T}] \mathrm{o}$ the northern races were assigned the virtues of self-reliance, initiative, individualism, and strength, whereas the southern races were seen as degenerate and lacking in energy and initiative. Canada was a northern country, and the myth of the northern race, a hardy race created by a stern and demanding climate, had been used to express Canadian nationalism and pride in country since Confederation. ${ }^{24}$

Such theories, however, could also be applied to South Africa, emphasizing the benefits of warm weather for health. If biological theories of race meant that a distinct hierarchy was created, other theories of environment introduced the possibility for assimilation. As Morag Bell notes for South Africa at this time, in acclimatization, sexual difference took on moral as well as ecological meaning, being tied to social and environmental change. ${ }^{25}$ Ironically, environmental determinist arguments added weight to the arguments of those who wanted to settle Canada with people other than the British occupying the positions that needed to be filled. This led to the contradiction that while assimilation may appear all-encompassing, on the one hand, on the other, biology determined that such assimilation was impossible for those of 'inferior stock'. Nevertheless, the belief in assimilation was strong and programmes to achieve it were carried out by the IODE with on-going determination. 
In practice, there was an on-going tension between race and immigration in Canada at this time, just as later on in the century there was between race and labour. There was a pragmatic need to expand the economy through an influx of immigrants who were prepared to perform heavy labour and farm work. The practical and economic concerns of federal government and the railways in settling the Canadian west ran counter to the ideological preoccupations of many Anglo-Canadian intellectuals; as Angus MacLaren argues: 'most realized that Canada needed immigrants to do the hard, dirty work of building a country, but they worried about the sort of country that would result ${ }^{\prime 26}$ Influential in the settlement of the Prairies, Clifford Sifton, minister of the interior in the Laurier Government from 1896 to 1905, saw the importance of the skills, as well as the origin, of the settler. ${ }^{27}$ While Sifton wanted farmers from the American mid-west and Britain, he perceived finding them to be a difficult task, and saw that the need might be met by peasant farmers from Europe, 'people who had been born on the land who were accustomed to a pioneering life ${ }^{\prime 28}$

The IODE, still in its organizing stages, was not yet well enough established on the Prairies to offer comprehensive services for new immigrants during the first ten years of the century, but it had definite ideas as to how Canada's immigrants should be recruited and assimilated, and, not surprisingly, exhibited a clear preference for immigrants from Britain. In 1907, the women of the IODE's St George Chapter of Toronto listened to an address by a Dr Kilpatrick in which he said:

Population, accordingly, is the need of the day. Multitudes are wanted to subdue physical nature to the uses of man and to afford the material basis for national greatness. But as long as immigration flows toward Canada a very large proportion will always consist of aliens. No sooner do these people touch our shores than the problem of assimilation and integration emerges for us in its profound difficulty. ${ }^{29}$

While the IODE did not want aliens, if they were to be admitted to Canada they would have to be quickly and effectively 'canadianized'. And so 'canadianization' emerged as the term for the assimilation of newcomers into Anglo-conformity. ${ }^{30}$

In the pre-First World War years, women's clubs, as 'surrogate mothers' for young women immigrants from diverse countries, were responsible for setting up a variety of Canadian welcome hostels. At a time of rigid patriarchal structures, the IODE saw a need for hostels to protect women upon arrival and was active in supporting such hostels, working with other women's organizations to supply board and training. The scope of the IODE's work was not as extensive as that of the YWCA 
or the Salvation Army, but none the less the IODE was very involved in these ventures, with the expressed purpose of keeping women, as Agnes Fitzgibbon said in a 1913 address on women's welcome hostels, 'safe from the temptations which assail them on every side in the new and strange surroundings far from home and their home influence' and to 'keep the purity of their womanhood and the future of new generation of which they are the potential mothers, for no one can count, no one can ever estimate the harm done by women who have lost their sense of womanhood'. ${ }^{31}$ Agnes Fitzgibbon was regent of the IODE Fitzgibbon Chapter of Toronto and superintendent of the Women's Welcome Hostel at 52 St Alban's Street, Toronto. Agnes Fitzgibbon and others of like mind considered that women's sexuality was clearly linked to nation building, and virtue would ensure respectable mothers for the next generation of Canadian citizens. ${ }^{32}$ In such an endeavour, although always keen to claim the glory for their own efforts, often at the expense of down-playing the work of others, there was a sense of collaboration between the various women's organizations.

The IODE differentiated immigrants, not only along racial and gender lines, but by class and age. Holding preferences for the 'right kind' of British migrant was, of course, neither new nor unique to the IODE. As the work of Marilyn Barber - and of Adele Perry for nineteenthcentury British Columbia - has shown, class preferences were idealistically commonplace. ${ }^{33}$ The IODE was pragmatic as well as idealistic about its class preferences, and was active in encouraging educated women of high social standing to emigrate to Canada. Again, it was hoped that hostels could 'isolate and educate' British women before they went out into the small towns where they were perceived to be at risk. ${ }^{34}$ Work by Marilyn Barber has shown that at the Queen Mary's Coronation Hostel in Vancouver, guests had to be 'gentlewomen', ${ }^{35}$ and, of course, of the preferred race as well. ${ }^{36}$ It was important that women immigrants be young, flexible and fertile. At a national meeting, a member contributed: 'I would say if they would send to us women of the right age they would be all right ... We had an example sent to us, by the Settlers' Welcome only last year; a lady of fifty, a trained nurse. Poor thing, what opportunity has she here , $^{37}$ This member was opposed to old women, 'whose ideas are set and formed', and who lacked the ability to adapt to Canada. Mrs Hannington, a British Columbia member reported to the national executive:

We see it out there; the English woman, they come out to our land, expensively educated, they can paint miniatures and play on the piano beautifully, but she does not know which end of her baby to hold uppermost 
... You give a Canadian or American woman a few yards of cheesecloth and a keg of nails and she will make you a drawing room while you wait. ${ }^{38}$

This statement suggests that living in Canada led to greater pragmatism and innovation, to 'the simplification of Europe overseas' ${ }^{39}$ Ironically, adaptability to the Canadian environment did not entail any change in British racial characteristics. The same member declared: 'and I think the children of the coast are the most beautiful in the world. They haven't lost their red English cheeks and the gold in their hair. ${ }^{40}$ There is a quandary here of whether acclimatization led to improvements in those already considered at the top of the constructed racial hierarchy. In this case it did not, although eugenic arguments would have suggested otherwise.

\section{Constructing the maternal during the First World War}

The patriotic sentiments responsible for the founding of the IODE during the South Africa War were quick to surface again at the outbreak of the First World War. In 1915, the president of the IODE proudly stated:

Every British woman is a daughter of the Empire, but when she joins our organization she then becomes a subject militant in the service of our king and country - in times of peace we drill and otherwise prepare ourselves, so that when the call to arms comes, we may be ready. Since the war began, we have considered ourselves on active service ... and we have responded nobly to the call. ${ }^{41}$

As British subjects, members of the IODE were simultaneously 'daughters' of the Empire. The power of the maternal was clearly important, as it was through such prevailing ideology that the IODE was able to contribute to fighting the war. Not only did the IODE work defensively during the First World War, but it concurrently produced articulate imperial, national and colonial ideologies that clarified Canada's place in the war - and, ultimately, in the Empire.

War is the time when identities become polarized into good or bad, for or against, friend or foe, enemy or compatriot. Despite the unification of a nation around one cause, providing new opportunities for women, war is also a time when gender identities are accentuated. The maternal identity was of particular significance to the IODE's place during the First World War. Genevieve Lloyd draws attention to how 'nurturant motherhood has been so readily enlisted in the cause of patriotism, which seems on the surface to be so much at odds with $\mathrm{it}^{\prime}{ }^{42}$ Lloyd shows how motherhood was constructed to support war and how, in giving up their sons, 'women are supposed to allow them to become real 
men and immortal selves. Surrendering sons to significant deaths becomes a higher mode of giving birth. Socially constructed motherhood, no less than socially constructed masculinity, is at the service of an ideal of citizenship that finds its fullest expression in war. ${ }^{43}$ To follow Lloyd, maternal identity was very important to the IODE, which valued a women's culture of activities and beliefs centred around mothering, and wanted to infuse a male-dominated public sphere with those values in order to 'keep the home fires burning'. The IODE's war effort involved the kind of voluntary work which was considered 'natural' and associated with mothering: providing food, clothing and bedding; setting up clubs and entertainment for soldiers; counselling the wounded; and giving emotional support to soldiers' families. The scale of IODE contributions during the First World War was spectacular. It included provision of 19 ambulances, 3 motor trucks, 2 automobiles, 22 sterilizing units, 12 operating tables, 3 huts for convalescent soldiers, 22 field kitchens, 942 cots, and equipment for 36 wards, plus thousands of knitted items. ${ }^{44}$

Strongly gendered distinctions were drawn between paid and voluntary work. When supplies and weapons were donated by the IODE, they were justified with an appeal to domesticity. Such was the case with the IODE's first project for the First World War, which was to provide a fully equipped hospital ship for the British Admiralty. The ship was feminized, and placed in a 'private' realm of care. Referring to the ship, the national executive noted: 'It is felt that this will be an opportunity [for] every Canadian woman to show her loyalty and devotion to the Empire and most fitting as it is the woman's part to minister to the sick and wounded. ${ }^{45}$

The privileged social position of IODE members was important in its war work. As noted in the previous chapter, membership was at its most elitist at the beginning of the First World War. More generally at the time, as Wayne Roberts's work on maternal feminism in Toronto from 1877 to 1914 indicates, elite women had considerable influence, despite being split in their positions on suffrage.$^{46}$ For the IODE, the presence of wealthy members influenced the scope of IODE projects since those members could afford to donate their homes, money and resources. There were some impressive examples. On 4 August 1914, just before war was declared, National President Gooderham called an emergency meeting at which it was decided to place the fully equipped hospital ship at the service of the British Admiralty. Collections were started, with a considerable boost being made by Lady Gibson of Hamilton who promised \$1,000, as did Mrs Gooderham herself. Mrs Herbert Molson of Montreal contributed \$2,500, and Lady Van Horne and Lady Drummond 
each sent $\$ 1,000$. HRH the Duchess of Connaught, at a meeting in Ottawa the same day, subscribed $\$ 1,000 .^{47}$ Soon afterwards, Mrs C. D. Crerar donated her home 'Dunedin', in Hamilton, as a hospital for convalescent soldiers. ${ }^{48}$ The names Good-erham, Molson and Van Horne signal extremely wealthy Canadian business interests in alcohol and the railways. These prominent IODE figures were the wives of elite businessmen, and as members of family dynasties were able to channel money into patriotic and philanthropic causes.

Consistent with the IODE's maternal identity, the meaning of 'home' was extended to encompass any place where the war took Canadians. In such locations the IODE provided safe havens, homes away from home. The IODE was quick to realize that the forces had leisure time and that hostels and clubs offered a way of regulating the behaviour of potentially wayward men. The IODE therefore set up the Royal King George and Queen Mary Maple Leaf Club in London, England, to serve as a safe house for Canadian soldiers, with preference given to officers on war leave. ${ }^{49}$ There meals and beds were provided; at the height of activity 1,200 beds were available every night. Contributing to this considerable undertaking, during the club's operation over a million meals were served. ${ }^{50} \mathrm{~A}$ home for nurses, less impressive, and a hospital on Hyde Park Road were also provided in London. The home for Canadian nurses at 95 Lancaster Gate was formerly the town house of Lady Minto, the IODE's first patroness. HRH the Princess Patricia opened the home and appreciation was expressed for 'the value and comfort of this haven of rest to the nurses after their trying, tedious and often most sorrowful duties'. ${ }^{51}$ The IODE's contribution can be read as a group of imperial daughters providing the comforts associated with their place in the domestic sphere of the family and as mothers of the nation, from the homefront of Canada to the frontlines of the war.

\section{Defending Britain and democracy}

Fighting to defend Britain was all-important to the IODE. During the South Africa War and the First World War, Canada was a junior partner, seizing a chance to prove its value to the imperial centre. Evidence of the shift to a stronger Canadian identity can be seen in IODE National President Gooderham's annual speech, in 1917: 'Is it not fitting that we, as Daughters of the Empire, should ask ourselves at this time if we are worthy of the sacrifices that so many noble spirits have made for our Empire? It is a never-to-be-forgotten demonstration of what a nation will do for a national ideal. ${ }^{52}$ To defend the Empire loyally, the IODE's First World War projects were imperial in scope, with the home for nurses a 
'concrete expression of the spirit of humanity that is binding the different portions and peoples of the Empire together in bonds that do not perish' ${ }^{53}$ Again the rhetoric indicates a sense of Canadian national identity amid the Empire's unity, the joining of 'the great members of the Anglo-Saxon family' who must come together to 'win and guarantee enduring peace for the World ${ }^{\prime}{ }^{54}$

To defend Britain, the IODE drew upon its maternal skills. Knitting had significant racial as well as gendered meanings. In Echoes in 1918 a caption under a picture of a young film star read: 'Two weapons of the Anglo-Saxon race are doing tremendous work to win the war for freedom - the bayonet of our soldiers and the needle of our loyal women. The knitting, the sewing, and the unparalleled helpfulness of women in all lines of activity have doubled the effectiveness of our men in the field. ${ }^{55}$ Knitting was also therapeutic and solitary, as expressed in a 1917 poem:

A peaceful valley in the West,

The evening shadows flitting;

A trembling heart, a glist'ning tear,

A lonely mother knitting.

Knit, Mother, Knit. The cross is thine;

The cross that mothers borrow;

For all must knit and some must mourn,

While war brings need and sorrow.

Dream, Mother, Dream. The night is here;

Dream that its shadows borrow;

A radiance from the great beyond,

To light a blest to-morrow. ${ }^{56}$

The benefits of work to the overcoming of grief were often expressed during the First World War years, with grief a domain for maternal help. An IODE postwar publication recalled: 'In the dark days of the world conflict the Order was a means of salvation to mind and body of many women (who had given their all) from a settled sorrow and despair, its activities provided a stimulus for alleviating their own grief in working for others, which alone constitutes true happiness. ${ }^{, 57}$ IODE members visited soldiers' wives and families. In 1915 Toronto's municipal chapter alone reported having made 5,029 visits. ${ }^{58}$ At the end of the war the IODE printed the words of the British prime minister, praising women for their bearing of 'their burden of sorrow and separation with unflinching fortitude and patience', as well as for their assuming of 'an enormous share of the burdens necessary to the practical conduct of the war'. ${ }^{59}$ Likewise, in a letter to IODE National President Gooderham, the commander of the Canadian armed forces, Sir Arthur Currie, endorsed 
the IODE's gendered work, writing that 'the men in the field will never forget the noble work of the mothers, wives and sisters during the war, now so happily past' ${ }^{60}$

The IODE was certainly not a pacifist organization. During the First World War the goal was victory for Canada and the Empire. Its military involvement refutes the arguments of some contemporary theorists, such as Jean Bethke Elshtain, who consider war and peace as opposites, with women as 'beautiful souls' and life-givers, and men as 'just warriors' and life-takers. ${ }^{61}$ For example, Sara Ruddick bestows upon women a 'preservative love', innate to their maternal experience. ${ }^{62}$ The IODE's support of war, while appealing to maternal identities, demonstrates the need to complicate the experience of women in times both of war and of peace, and question whether women are by nature, socialization, ideology or experience more pacific than men. ${ }^{63}$ Indeed, representation of women and war is now a focus of research, ${ }^{64}$ with new attention to how images of women are constructed, and what functions they serve. Through such an approach women's responses to war become much messier; and, to follow Ruth Roach Pierson, 'there has not been a consistent women's response to war and revolution any more that there has been a uniform feminist position on women's relation to organized violence' ${ }^{65}$

Given its goal of victory, it is not surprising that the IODE persuaded men to enlist and was an active campaigner for compulsory military service. In Victoria the IODE held a 'silent recruiting week' for one battalion, with each member wearing a badge urging enlistment. ${ }^{66}$ It is also not surprising that the IODE took strong objection to the peace movement. Its opposition was singular and focused:

It is not too much to say that the continuance of the present war depends upon the support of the women of the Empire, so that any discussion which may confuse the issue must be regarded as dangerous. The women know that this generation has been called upon to make tremendous sacrifices in order to leave peace and liberty in the world for their children and their children's children. That is the reason why peace talk, no matter how sincere, cannot be tolerated. ${ }^{67}$

The IODE's position was justified by a call to the maternal. Women, from their moral and nurturing position, were to make sacrifices for future generations. Thus the 'private sphere' justification echoed the 'public sphere' Tory politics of conserving for future generations, demonstrating the interconnectedness of what were constructed as separate spheres.

The IODE expressed a strong disdain for Germany, and in 1916 associated itself with the Anti-German League, stating: 
The purpose of the Anti-German League is not to perpetuate international hatreds. It is simply a sane measure of self-preservation aimed against a nation which has made itself an outlaw of civilization. All members who join this league pledge themselves never willingly or knowingly to buy German or Austrian goods, and to do their utmost to prevent such goods beings brought into Canada either now or after the war. ${ }^{68}$

Boycott was a wartime strategy, but the violence of the expression is striking. In 1915 Mrs P. D. Crerar suggested the pledge, 'From this day until the day of my death I pledge myself never willingly nor knowingly to buy an article made by the bloody hands that killed our boys. ${ }^{69}$ Fearing for the safety of Canadian prisoners in Germany, the IODE suggested that the pledge be made in secret. ${ }^{70}$

It is easy to understand, in a nation at war, a belief in the cause and a rallying of beliefs to secure victory. Specific episodes suggest a convergence in perceptions of both race and gender in the defence of the Empire. When, in 1915, the British nurse Edith Cavell was executed by the Germans in Belgium on a charge of 'escorting troops to the enemy', gender sharpened the sense of outrage expressed empirewide. $^{71}$ The IODE chapter bearing her name, and appropriately comprised of Montreal nurses, was one of the many Cavell memorials that sprung up around the Empire. ${ }^{72}$ It was stated in Echoes after the close of the war:

Among all the horrible deeds perpetrated by the Germans during the great war none perhaps excited more loathing and disgust in the minds of British people than the brutal murder of this gloriously loyal Englishwoman . . Her execution can only be regarded as a brutal murder, and another illustration of the many which the Germans have given in the late war, that in spite of all their vaunted culture they are in fact still a semi-barbarous people and destitute of the very elements of any true culture. ${ }^{73}$

This was an attack on a white British woman, a symbol of purity and the Empire, in which she was rendered defenceless by an enemy constructed as racially inferior and barbaric.

Despite the maternal identity that it cultivated as a representative of the Empire, in maintaining a patriotic purpose supportive of the status quo the IODE did not limit its work solely to issues that concerned gender. This would lead the IODE to fall out of agreement with other women's organizations. For example, in 1919 the IODE resigned from the National Council of Women of Canada to protest the Council's affiliation with the International Council of Women, on the grounds that the latter included 'enemy' affiliates. ${ }^{74}$ Given that the IODE was first and foremost a patriotic organization, its resignation is not surprising. It 
demonstrated the multiple positioning of the IODE as a patriotic group of women with the primary objective of winning the war for Britain and the Empire.

\section{Votes for women}

Despite its primarily patriotic endeavours and its general support of women's traditional place in society, highlighting the complexity of conservative women and feminism, in 1917 the IODE was at the centre of a key feminist cause when the issues of suffrage and conscription converged to achieve victorious outcomes. By the advent of the First World War, Canada had a strong women's suffrage movement that was tapped into and was a part of an international movement and a first wave of feminism. Within a decade of Canadian confederation, in 1867, though with the exception of Quebec, the push for women's suffrage had taken hold. Canada's federal system, with a House of Representatives and a Senate, as well as provincial government, meant that agitation had to take place in a variety of arenas in order to be effective. By the end of the nineteenth century, there were organizations active in Ontario, the western provinces and the Maritimes. Bills were introduced in provincial legislatures and petitions were signed. The campaign exhibited a Canadian quality in its orderliness, lawfulness and lack of confrontational tactics seen elsewhere. ${ }^{75}$

How was it that the IODE came to play an important part in the granting of suffrage to women? Julia Bush has identified that in Britain there were rifts between 'imperial feminists', those women who were a part of overtly feminist groups with suffrage as their primary cause, and 'female imperialists', women, such as those of the Victoria League, who had patriotism as their primary cause and who advocated conservative politics. ${ }^{76}$ It appears that such divisions were not as strong in Canada as they were in Britain, with the differences between groups less demarcated. Some members of the IODE were supporters of suffrage, while others were not. This was not the case among women's patriotic organizations in Britain at the time. As a place with more fluid class relations, and as a 'colony', Canada was different. Carol Lee Bacchi has suggested that Anglo-Celtic, Protestant, well-educated elite women and wives of professionals were sympathetic to the objectives of the suffrage. ${ }^{77}$ As the case of the IODE shows, it was not as simple as that all such women supported suffrage, but, certainly, among the membership there were suffragists, most notably Constance Hamilton. It is not surprising, then, that in recognizing the diversity of opinions among its membership the IODE, as an officially non-partisan organization, did not 
explicitly endorse the franchise for women. In fact, in 1916, the IODE national executive appeared to put issues other than winning the war 'in abeyance', urging 'all patriotic women to concentrate all their energy, strength and means upon the immediate war $^{\prime} .^{78}$

A year later, however, conscription was the hinge issue in the election facing Borden's Conservative Government. By the time the Conservatives joined forces with the pro-conscription wing of the Liberal Party, forming the Union Government Coalition on 12 October 1917, the IODE had become active in doing all that it could to bring about conscription. It couched its support for the Union Government with its old rhetoric of securing a 'decisive victory in the war'. ${ }^{79}$ At this time, National President Gooderham, along with IODE member Constance Hamilton in her capacity in the Canadian Suffrage Association, and the presidents of the National Council of Women and the WCTU, at the request of the prime minister, tested the effect that a selective female franchise would have on the election. The result was the controversial 1917 Wartime Elections Act that boosted the support for conscription by excluding from voting all conscientious objectors and those born in foreign countries and naturalized since 1902; and muting French Canadian and other dissenting voters by extending the franchise to women who were British subjects 21 years of age or over with a close relative serving in the armed forces of Canada or Great Britain. ${ }^{80}$

Hence, after years of struggle, approximately 500,000 women in Canada won the vote. ${ }^{81}$ In supporting conscription with the objective of winning the war, the IODE was directly implicated in this fundamental step towards securing the vote for all women in Canada. The IODE went so far as to make it clear that members should use their vote 'and influence as a citizen in the campaign to secure a government that will press the war aggressively to a victorious conclusion' ${ }^{82}$ It was Catherine Cleverdon's 1950 contention that it was the hard work of women in the war effort that convinced politicians of the worth of giving women the vote. ${ }^{83}$ That being the case, as the largest patriotic organization in the Empire, along with other organizations such as the YWCA and the Red Cross, the IODE made a strong contribution here. Always at the forefront were the issues of motherhood and morality, and of seeking justice for the men in the forces overseas.

During the IODE's first years, immigration and war work had in common the intended construction of a strong British Canada. The IODE was able to use its elite social status and gender to achieve its objectives. It supported a 'racial hierarchy' which asserted that British people and their Anglo-Celtic Canadian descendants were superior to all other races, and discriminatory immigration laws which legislated this 
preference. The First World War provided the opportunity for the IODE to draw upon prevailing strong constructions of the maternal to defend the Empire. Its maternal position was vitally connected to an idealization of an Anglo-Celtic race: it was female British subjects who were given the vote in 1917. Founded to rally to the cause of the South Africa War, fighting for the 'mother country' as loyal 'daughters' during the First World War the IODE acted out its motives on a far larger scale than it had imagined in 1900. Membership peaked during the war, and was never again to climb to the 50,000 it then reached. An IODE member and author of a Masters' thesis on the IODE centred her studies on the first twenty-five years, 'because it was the cornerstone for the whole organization, because everything else has been elaborated or detracted from that twenty-five years . . . they covered so much in . . . [those] years'. ${ }^{84}$ Indeed, the IODE's organizing principles would shift over the century, but the formative years provided the base that, as the rest of this book will show, remained of importance in its attitudes towards gender, race and class. The war also solidified the IODE's sense of national identity, albeit within the British Empire, and strengthened its resolve to go on the offensive and 'canadianize' immigrants during the postwar years.

\section{Notes}

1 Echoes, 18 (October 1904), 6.

2 Dominic David Alessio, 'Domesticating "the heart of the wild": female personifications of the colonies, 1886-1940', Women's History Review, 6: 2 (1997), $239-69$, at 249.

3 Anna Davin, 'Imperialism and motherhood', History Workshop, 5 (1978), 9-65.

4 See Mariana Valverde, "When the mother of the race is free": race, reproduction, and sexuality in first-wave feminism', in Franca Iacovetta and Mariana Valverde (eds), Gender Conflicts: New Essays in Women's History (Toronto: University of Toronto Press, 1992), 3-26; and Mariana Valverde, The Age of Soap, Light and Water: Moral Reform in English Canada 1885-1925 (Toronto: McClelland \& Stewart, 1991).

5 Kay Anderson, Vancouver's Chinatown: Racial Discourse in Canada, 1875-1980 (Montreal and Kingston: McGill-Queen's University Press, 1991).

6 John Porter, The Vertical Mosaic (Toronto: University of Toronto Press, 1965). Porter's study was the first to critically investigate differences in the social situation of 'English' Canadians. More recent works on Canadian 'British ethnicity' have been Pauline Greenhill, Ethnicity in the Mainstream: Three Studies of English Canadian Culture in Ontario (Montreal and Kingston: McGill-Queen's University Press, 1993); Ross McCormack, 'Networks among British immigrants and accommodation to Canadian society: Winnipeg, 1900-1914', Histoire sociale/Social History, 17:34 (1984), 357-74; and Ross McCormack, 'Cloth caps and jobs: the ethnicity of English immigrants in Canada, 1900-1914', in Jorgen Dahlie and Tina Fernando (eds), Ethnicity, Power and Politics in Canada (Toronto: Methuen, 1981), 38-57.

7 Greenhill, Ethnicity in the Mainstream, 157. 


\section{ORGANIZING PRINCIPLES, 1900-19}

8 Catherine Hall, White, Male and Middle-Class: Explorations in Feminism and History (New York: Routledge, 1992), 206. See also Catherine Hall, "'From Greenland's icy mountains ... to Afric's golden sand": ethnicity, race and nation in mid-nineteenth-century England', Gender and History, 5: 2 (1993), 212-30.

9 Robert Young, Colonial Desire: Hybridity in Theory, Culture and Race (London and New York: Routledge, 1995).

10 Greenhill, Ethnicity in the Mainstream, 153.

11 Howard Palmer, 'Reluctant hosts: Anglo-Canadian views of multiculturalism in the twentieth century', in Gerald Tulchinsky (ed.), Immigration in Canada: Historical Perspectives (Toronto: Copp Clark Longman Ltd, 1994), 297-333, at 300.

12 James S. Woodsworth, Strangers at Our Gates or Coming Canadians, 2nd edn (Toronto: University of Toronto Press, 1972 [Young People's Forward Movement Department of the Methodist Church, 1909]).

13 Valerie Knowles, Strangers at Our Gates: Canadian Immigration and Immigration Policy, 1540-1990 (Toronto: Dundurn Press, 1992), 78.

14 Freda Hawkins, Critical Years in Immigration: Canada and Australia Compared (Montreal and Kingston: McGill-Queen's University Press, 1989), 17. This important clause was to be active for fifty years.

15 Marilyn Barber, 'Introduction' to 2nd edn of Woodsworth, Strangers at Our Gates, xiv.

16 Angus MacLaren, Our Own Master Race: Eugenics in Canada 1885-1945 (Toronto: McClelland \& Stewart, 1990), 23.

17 Ibid., 15.

18 Ibid., 49.

19 Ibid., 165.

20 Carol Lee Bacchi, Liberation Deferred? The Ideas of the English-Canadian Suffragists, 1877-1918 (Toronto: University of Toronto Press, 1983); and 'Race regeneration and social purity: a study of the social attitudes of Canada's English-speaking suffragists', Histoire sociale/Social History, 11: 22 (1978), 460-74; Valverde, The Age of Light, Soap, and Water.

21 David N. Livingstone, The Geographical Tradition: Episodes in the History of a Contested Enterprise (Oxford, and Cambridge, MA: Blackwell, 1993).

22 Ellsworth Huntington, The Character of the Races, as Influenced by Physical Environment, Natural Selection, and Historical Development (New York: Scribner, 1924); Griffith T. Taylor, 'The evolution and distribution of race, culture, and language', Geographical Review, 11 (1921), 54-119.

23 Livingstone, The Geographical Tradition, 221.

24 Barber in Woodsworth, Strangers at Our Gates, xiv.

25 See Morag Bell, 'A woman's place in "a white man's country": rights, duties and citizenship for the "new" South Africa, c. 1902', Ecumene, 2: 2 (1995), 129-48; and "The pestilence that walketh in darkness": imperial health, gender and images of South Africa c. 1880-1910', Transactions of the Institute of British Geographers, 18 (1993), 327-41.

26 Angus MacLaren, Our Own Master Race, 48.

27 Hawkins, Critical Years in Immigration, 5.

28 Ibid.

29 Echoes, 28 (June 1907), 40.

30 MacLaren, Our Own Master Race, 47.

31 Echoes, 52 (June 1913), 29-31. The first hostel was started in Winnipeg.

32 For a discussion of motherhood in Canada at the time, see Katherine Arnup, Andree Levesque and Ruth Roach Pierson (eds), Delivering Motherhood: Maternal Ideologies and Practices in the Nineteenth and Twentieth Centuries (London and New York: Routledge, 1990). 
33 In particular see Marilyn Barber, 'The gentlewomen of Queen Mary's Coronation Hostel', in Barbara K. Latham and Roberta J. Pazdro (eds), Not Just Pin Money (Victoria: Camosun College, 1984), 141-58; and Adele Perry, "'Oh I'm just sick of the faces of men'"

34 NAC MG28 I 17, 11, 5, 51.

35 Barber, 'The gentlewomen', 150. See also James Hammerton, Emigrant Gentlewomen: Genteel Poverty and Female Emigration, 1830-1914 (London: Croom Helm, 1979).

36 Marilyn Barber, Immigrant Domestic Servants in Canada (Ottawa: Canadian Historical Association with Government of Canada's Multiculturalism Programme, 1991). At that time, the IODE was less concerned than were others over the numbers of domestics and other nationalities entering Canada.

37 NAC MG28 I 17, 11, 5, 51, 1913, IODE National Executive Minutes. Mrs WilsonSmith is speaking.

38 NAC MG28 I 17, 11, 5, 49, 1913, IODE National Executive Minutes.

39 For developments of this argument see R. C. Harris, "The simplification of Europe overseas', Annals of the Association of American Geographers, 67: 4 (1977), 469-83.

40 NAC MG28 I 17 11, 5, 46.

41 NAC MG28 I 17, 11, 7, 1915 National Meeting, Halifax. President's speech.

42 Genevieve Lloyd, 'Selfhood, war and masculinity', in Carol Pateman and Elizabeth Gross (eds), Feminist Challenges: Social and Political Theory (Boston, MA: Northeastern University Press, 1986), 63-76, at 76.

43 Ibid.

44 A Brief History of the IODE (Toronto: IODE National Headquarters, 1981).

45 NAC MG28 I 17, 2, 3, 119, 4 August 1914, National Executive Meeting.

46 See Wayne Roberts, "Rocking the cradle for the world": the new woman and maternal feminism, Toronto, 1877-1914', in Linda Kealey (ed.) A Not Unreasonable Claim (Toronto: Women's Press, 1979), 15-46. Roberts provides a discussion of Toronto elites, suffrage and activism.

47 J. Castell Hopkins, The Canadian Annual Review of Public Affairs 1914 (Toronto: Annual Review Publishing Co.), 232.

48 J. Castell Hopkins, The Canadian Annual Review of Public Affairs 1915, 209.

49 NAC MG28 I 19, 1, King George and Queen Mary Maple Leaf Club Minutes 1915. The first meeting of the organizers was held on 23 June 1915 in Mrs Rudyard Kipling's rooms. The largest individual donations were from Sir Thomas Shaughnessy, Lady Drummond, Lady Peiley, Lindsays, Mrs Rudyard Kipling, McLennans. The IODE's Manitoba Souvenir 1916 (RCSL) records that the premises was purchased by Mrs Gooderham.

50 Echoes, 78 (1919-20), 57. The sum of approximately $\$ 40,000$ was raised by voluntary subscription, and that was supplemented by donations from the Ontario government.

51 NLC, IODE 1900-1925, 13.

52 Echoes, 69 (October 1917), 13.

53 Echoes, 73 (June 1918), 3.

54 Ibid., 155. The article goes on to state that 'the Hand that Rocks the Cradle is the hand that keeps the Ship of State from Rocking'.

55 Echoes, 72 (May 1918), 29.

56 Chas J. North, 'Women of the West work to support our boys in the trenches', Echoes, 69 (October 1917), 31

57 NLC, 'IODE 1900-1925', 15.

58 Castell Hopkins, Canadian Annual Review 1915, 333.

59 Echoes, 75 (December 1918), 15, statement by David Lloyd George.

60 Echoes, 76 (March 1919), 9, letter to Gooderham from Sir Arthur Currie dated and addressed 26 December 1918, Headquarters of the Canadian Army Corps.

61 J. Elshtain, Women and War (New York: Basic Books Inc., 1987). 


\section{ORGANIZING PRINCIPLES, 1900-19}

62 Sara Ruddick, Maternal Thinking: Toward a Politics of Peace (Boston, MA: Beacon Press, 1989).

63 H. M. Cooper et al. (eds), Arms and the Woman: War, Gender, and Literary Representation (Chapell Hill: University of North Carolina Press, 1989), xv.

64 For examples see S. MacDonald, P. Holden and S. Ardener (eds), Images of Women in Peace and War: Cross Cultural and Historical Perspectives (London: Macmillan, 1987); and Claire M. Tylee, The Great War and Women's Consciousness: Images of Militarism and Womanhood in Women's Writings, 1914-64 (Basingstoke: Macmillan, 1990).

65 Ruth Roach Pierson, "Did your mother wear army boots?". Feminist theory and women's relation to war, peace and revolution', in MacDonald, Holden and Ardener, Images of Women in Peace and War, 255.

66 Castell Hopkins, Canadian Annual Review 1915, 783.

67 Editorial on peace movements, Echoes, 60 (December 1915).

68 'The Anti-German League', Echoes, 66 (December 1916), 8.

69 NAC MG28 I 17, 2, 3, National Executive Meeting Minutes, 8 October 1915.

70 Ibid.

71 See Katie Pickles, 'Edith Cavell - heroine: no hatred or bitterness for anyone?', History Now, 3: 2 (1997), 1-8.

72 Marcel Dirk, 'The Imperial Order Daughters of the Empire and the First World War', unpublished MA dissertation, Carleton University, Institute of Canadian Studies, $1988,59$.

73 Article on Edith Cavell, Echoes, 77 (June 1919), 33-5.

74 Veronica Strong-Boag, The Parliament of Women: The National Council of Women of Canada 1893-1929 (Ottawa: National Museums of Canada, 1976), 105.

75 A History of the Vote in Canada (Ottawa: Minister of Public Works and Services Canada, 1997), 62-8.

76 Julia Bush, 'Edwardian ladies and the "race" dimensions of British imperialism', Women's Studies International Forum, 21: 3 (1998), 277-89, at 282.

77 Bacchi, Liberation Deferred?, 149.

78 NAC MG28 I 17, 2, National Executive Minutes, 6 December 1916.

79 NAC MG28 I 17, 2, National Executive Minutes, 17 October 1917.

80 Catherine Lyle Cleverdon, The Woman Suffrage Movement in Canada (Toronto: University of Toronto Press, 1950), 123.

81 Ibid., 129.

82 NAC MG28 I 17, 2, National Executive Minutes, 17 October 1917.

83 Cleverdon, The Woman Suffrage Movement, 119.

84 Doreen Hamilton, 'Origins of the IODE: a Canadian women's movement for God, king and country, 1900-1925', unpublished MA dissertation, Department of History, University of New Brunswick, 1992. Information from interview, 25 October 1993: Saint John, New Brunswick. 